\title{
THE EFFECT OF JOB PERFORMANCE THROUGH ORGANIZATIONAL CULTURE, WORK ENVIRONMENT, PERSONALITY, AND MOTIVATION
}

\author{
Virgana Virgana \\ Pascasarjana Universitas Indraprasta PGRI \\ Jl. Namgka No 58c, Tanjung Barat, Jagakarsa, Jakarta Selatan \\ Email: virganaunindra@gmail.com
}

\begin{abstract}
The dominant factor to achieve a school's competitiveness is the performance of headmasters. This study aimed to determine the direct and indirect influence of organizational culture, work environment, personality, and motivation on the performance of principal of state senior high schools. Research samples were 310 principals of state schools in Jakarta. Data analysis used a path analysis of which requirements were the test of normality, homogeneity, and linearity. The results of the research there were direct influence exogenous variables on endogenous, and there was indirect influence of personality through motivation on the job performance. Increased job performance could be done by coaching the headmaster about the culture, environment, and personality.
\end{abstract}

Keywords: Job performance, organizational culture, work environment, personality, motivation.

\section{Introduction}

The progress of school performance is determined by the management of the principal, as the leadership of the education organization must perform the vision and mission through five element of management. Planning, organizing, command, co-ordination, and control (Fayol \& Storrs, 1954). In particular, the duties and functions of the principal in Indonesia are to carry out the main managerial tasks, entrepreneurship development, and supervision to the teachers and education (Permendikbud Nomor 6, 2018).

The leadership of the headmaster is very dependent on various aspects, namely its environment, its infrastructure means, how the pattern of implementation, human resource support, and institutional and the concepts of accurate and clear (Nai \& Wiwik, 2018). The progress of an organization depends on the personality of the leader, according to the opinions of (Najam-usSahar, 2016) that If we find that what personality type is appropriate for a job then it can be a tool to choose the right person for the right job. It can be a base in recruiting process for recruiters and have a positive impact on organization's performance. The more recognized the university's employees' contributions to the organizational performances are, the more motivated and involved the employees become (Zlate \& Cucui, 2015).

In an organization, job performance is one of the outcomes individuals who are influenced by va-rious factors. As outlined by Colquitt, LePine, dan Wesson (2019) that outcomes of individuals in the organization in the form of job performance and organizational commitment. Both of these things are influenced by 1) job satisfaction; 2) stress; 3) motivation; 4) Trust, Justice, \& Ethics, 5) learning \& decision making. These were influenced by: 1) organizational culture; 2) organizational structure; 3) learning style \& behavior, 4) leadership power \& influence, 5) team processes; 6) team Characteristic; 7) personality and culture; and 8) ability.

While according to (Gibson, Ivancevich, Donnelly Jr., \& Konopaske, 2012) In the Model Path-Goal theory, job satisfaction and performance are essentially outcomes influenced by follower/subordinate perception and work motivation. Both of them are also influenced by various factors, among them: leaders' behavior/ styles, follower/subordinate characteristics), dan environmental factors. Therefore, the title of this study is "enhancing job performance through organizational culure, work environment, personality, and work motivation". The study to determine the direct influence of organizational culture, work environment, and personality on motivation, then to determine the direct influence of organizational culture, work environment, personality, and motivation on job performance, and indirect influence of organizational culture, work environment, personality through work motivation on the performance of principal of state elementary school, junior high school and senior high schools.

Organizational culture has emerged as a new aspect of business management since the 1980s, and is recognized as a means to actively cope with the rapidly changing environment (Nam \& Kim, 2016). The 
direct link of culture with behavior has been identified as problematic (Borys, 2014). The kind of organizational culture is supported by an open system that promotes the willingness to act. Some organizational cultures favor an unequal or hierarchical distribution of power, while others adopt values and norms that foster an equal or egalitarian distribution of power (Janićijević, Nikčević, \& Vasić, 2018). Organizational culture is based on cognitive systems, which help to explain how employees think about and make a decision (Nwakoby, Okoye, \& Anugwu, 2019). It is necessary to grasp the culture of each organization and enhance the understanding of industry-specific culture to grasp the culture of a new fusion organization (Nam \& Kim, 2016). Thus it can be said that organizational culture is an important part of the organization's life to determine the direction of how something runs in an organization, according to the rules and values applicable in that organization.

Environment, we argue that when employees perceive an appositive and supportive work environment, they will produce positive work outcomes in response to the favorable treatment by their organization (Teo, Bentley, \& Nguyen, 2019). Improving a learning work environment that might reduce conflict, disable resistance, and encourage tolerance for uncertainty and ambiguity (Farhan, 2018). Positive work environment perceptions, organizational encouragement as well as supervisory encouragement are assumed to be important determinants of participation intention in firm-internal executed innovation contests (Hober, Schaarschmidt, \& von Korflesch, 2019). Work environment refers to the atmosphere of an organization where employees do their works (Hanaysha, 2016). Work environment involves all the aspects which act and react on the body and mind of an employee (Jain \& Kaur, 2014). Thus it can be said that the work environment is an important part of the organization's life to determine employees can work comfortably that can create a pleasant atmosphere.

Personality can be described as the characteristics of someone act in a certain way (Ghani, Yunus, \& Bahry, 2016). Personality represents a core of relatively stable individual differences in which alterations can be intentionally induced or can occur naturalistically (Chapman, Roberts, \& Duberstein, 2011). Big Five Personality (neuroticism, extraversion, openness, agreeableness, and conscientiousness) traits model has divided the personality into five broad traits, these are more useful in identifying different kinds of job-related attitudes and behaviors (Thiruvarasi \& Kamaraj, 2017). Aside from the Big Five traits, other personality conceptualizations, such as Need for Cognition, have similarly been linked to cognitive outcomes in old age. Need for
Cognition conceptualizes individual differences in the tendency to seek out and enjoy cognitively demanding activities (Cacioppo \& Petty, 1982). In view of personality disposition, forgiveness refers to the tendency of individuals to forgive others in interpersonal situations (Safaria, Tentama, \& Hadi, 2016). Thus it can be said that organizational personality is an important part of the Organization's life to determine in determining the type of work that is suitable for employees.

Most researchers would implicitly agree that there are individual differences in motivation, and these differences can be traced to dispositional tendencies (Judge \& Ilies, 2002). Leaders' motivation for sustainability should have a direct and positive effect on the likeliness of firms adopting a sustainability strategy (Eide, Saether, \& Aspelund, 2020). Some issues of motivation in the education process can be related to the issues of work motivation, because children observe and learn the interests, values, and attitudes towards the responsibilities of their parents (Berková \& Krejčová, 2016). Motivation is a highly complex psychological process, involving the nervous activity, cognition, emotional realm and the stable personality traits that allow people to interact with their environment (Fandiño, Muñoz, \& Velandia, 2019). Motivation theories talk about: intrinsic motivators, a person's internal desire to do something, due to such things as interest, challenge, and personal satisfaction, and extrinsic motivators Motivation that comes from outside the person and includes such things as pay, bonuses, and other tangible rewards (Langton, Robbins, \& Judge, 2016). The fullest type of internalization, which allows extrinsic motivation to be truly autonomous or volitional, involves the integration of an identification with other aspects of oneself - that is, with other identifications, interests, and values (Gagné \& Deci, 2005). The argument about the superiority of intrinsic motivation usually relates to its nature, that is, it originates from within the individual and is independent of external influences. Instead extrinsic motivation, that is to say, such motivation would disappear as soon as the reward or punishment was withdrew (Zhu \& Leung, 2011). The findings prove that money, salary or bonus just have small influence to work motivation (Sutanto et al., 2018). Thus it can be said that motivation is an important part of the organization's life to determine the employee of how employee's interest in the activity organization, according to intrinsic and extrinsic motivation.

Job Performance is an achievement stage as a work accomplishment by an individual from the organization (Eliyana, Ma'arif, \& Muzakki, 2019). Performance is a 
condition the level of achievement of results an organization associated with the vision and mission of an organization run (Virgana, 2018). Job performance has been identified as a significant key for organizations to gain competitive advantage and superior productivity (Singh, 2016). Job performance also ensures the organization is functioning well and it consists of the knowledge and skills that able to guide the employees to perform a variety of activities (Ghani et al., 2016). The role of performance based reward management as an important predicting variable is consistent with the notion of leadership theory (Ismail, Anuar, \& Abdullah, 2016). The job performance of employees plays a crucial factor in determining an organization's performance (Farooqui \& Nagendra, 2014). The performance assessment of civil servants is used as a control of productive work behavior to achieve agreed work results and not an assessment based on the personality of a civil servant (Mextaria, Sukmawati, \& Hubeis, 2019). Thus it can be said that Job Performance is an important part of the organization's life to gain competitive advantage, achieves stage as a work accomplishment by an individual.

This study is to determine the influence directly organizational culture, work environment, personality, and motivation on headmaster performance. And to determine the influence indirectly of organizational culture, work environment though variables intervening on headmaster performance. More specific study questions are formulated as follows. Is there a direct influence organizational culture on work motivation? Is there a direct influence on work environment on work motivation? Are there any significant direct influences of personality on work motivation? Is there a direct influence organizational culture on headmasters' performance? Is there a direct influence on work environment culture on headmasters' performance? Are there any significant direct influences of personality on headmasters' performance? Is there a direct influence motivation on Headmaster's performance? Is there an indirect influence organizational culture through motivation on headmasters' performance? Is there an indirect influence on work environment on headmasters' performance? Is there an indirect influence of personality on headmasters' performance?

Based on the description and the question study, the hypothesis formulation of this research that there is a direct influence of:

$H_{1}$ : Organizational culture on work motivation

$\mathrm{H}_{2}$ : Work environment on work motivation

$\mathrm{H}_{3}$ : Personality on work motivation

$\mathrm{H}_{4}$ : Organizational culture on job performance

$\mathrm{H}_{5}$ : Work environment on job performance
$H_{6}$ : Personality on job performance

$H_{7}$ : Motivation towards job performance

And the indirect influence of:

$\mathrm{H}_{8}$ : Organizational culture on job performance through motivation

$H_{9}$ : Work environment on the job Performance through motivation

$H_{10}$ : Personality on job performance through motivation

Based on the theories outlined, the researchers develop the hypothesis and shown in Figure 1.

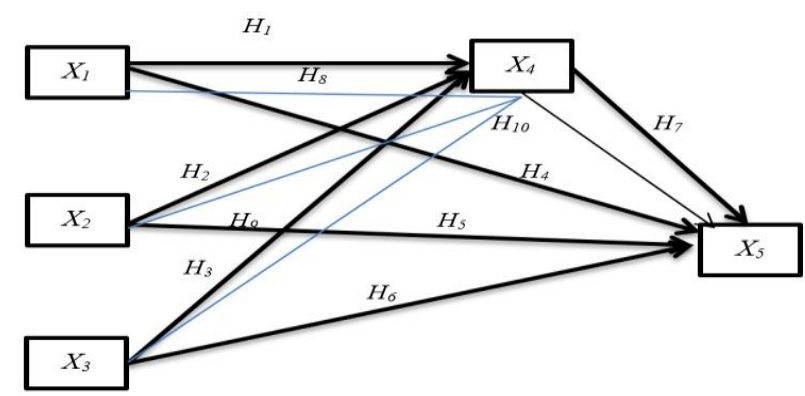

Figure 1. Conceptual framework of the study

Description:

$X_{1}$ : Organizational culture

$X_{2}$ : Work environment

$X_{3}$ : Personality

$X_{4}$ : Work motivation

$X_{5}$ : Job performance

\section{Research Methods}

This study was quantitative with the type of causal research; data processed using path analysis, the study was held in November 2019 to March 2020. The population of this study was 2,216 principals of which 1,109 principals of junior high schools; 510 principals of senior high schools; 606 principals of vocational high school in Jakarta (population with strata). Based on the population Table 2, 216 of sampled sampling studies rounded as much as 310 with random technique stratified sampling, retrieved 310 participants (principals), with proportional way of which 155 principals of junior high schools, of which 71 principals of senior high schools, of which 84 of vocational high schools, of which $136(44 \%)$ were males and $174(56 \%)$ were females, the age between 27-56 years old, 192 (62\%) were bachelor degree holders, 71 (23\%) master degree holders, and $47(15 \%)$ were doctor degree holders. A total of $56(16 \%)$ employees had served between $0-5$ years, $68(22 \%)$ employees had served between 6-11 years, 71 (23\%) employees had served between 12-17 years, 
53(17\%) employees had served between 18-22 years, 47(15\%) employees had served between 23-27 years, $15(5 \%)$ employees had served between $27-32$ years.

To obtain research data using questioners, there were five sets of questioners: organizational culture, work environment, personality, motivation, and job performance. The rating scale used for all variables has five categories of the answer options, namely: (a) always; (b) often; (c) sometimes; (d) infrequently; and (e) never. Alternate answers are weighted by a value of 5 to 1 for a positive statement, and a weight value of 1 to 5 for negative statements. The questionnaires were divided into two parts. Part 1 demographic data, in this section the respondents were asked to complete the questionnaire, such as age, gender, degree holders, work experience, and subject. Part 2 the items of five variables, in this section, the respondent was asked to answer questions in the questionnaire of which 30 items of organizational culture, work environment, personality, motivation, and job performance. The development of research instruments is pursued in several ways, namely: (a) to determine the conceptual definition (b) to develop a research variable indicator; (c) to compile the grid of instruments; to conduct test instruments: validity testing and instrument reliability (Riduwan, 2011).

\section{Results and Discussion}

Data analysis requirements are performed before the instrument is used in research, then researchers do validity and reliability tests, the validity of instrument items was determined by comparing the value of $r_{x y}$ obtained with the critical $r$ value Pearson's Product Moment at $n=20$, outsides of the sample. If $r_{\text {count }}>r_{\text {table }}$, then the instrument item is valid and is used for data collection. Conversely, if $r_{\text {count }}<r_{\text {table }}$, then the item becomes invalid and was not used in the study. In the critical value Pearson's table product moment is known to be $\left(r_{\text {table }}=.360\right)$ for $n=20$ with $\alpha=$ .05 . The validity test of organizational culture instruments was performed with the help of Microsoft Excel. After calculating the validity of the instrument test and the result of 30 items of which 28 were valid and two invalid item; 27 were valid and three invalid items for work environment; 28 were valid and two invalid items for personality; 28 were valid and two invalid items for motivation; 29 were valid and one invalid item for job performance. The reliability of the items of valid instruments was then analyzed by the Cronbach Alpha technique; the calculation is done using Excel for the Windows program as seen in Table 1.
Data analysis requirements of a path analysis are analysis of data normality, data homogeneity, a test of significance and linearity of the regression coefficient.

\section{Test the Normality Distribution Error}

The first requirement to be met in a path analysis is that the sampling error must originate from a population that is normally distributed. Test the normality error data is performed to know that the distribution of the observed sample error comes from a population that is on a normal distribution or not. Test statistics conducted to test the normality of distribution errors in this study are the test of Lilliefors. The provisions in this test are all the statistics Sig. (2-tailed) $<.05$ then the error data is normally distributed.

Table 1

Reliability Statistics for Each of the Variables

\begin{tabular}{lccl}
\hline \multicolumn{1}{c}{ Variable } & $n$ & $\begin{array}{c}\text { Cronbach's } \\
\text { Alpha }\end{array}$ & Result \\
\hline Organizational culture & 28 & .914 & Reliable \\
Work environment & 27 & .917 & Reliable \\
Personality & 28 & .912 & Reliable \\
Motivation & 28 & .918 & Reliable \\
Job performance & 29 & .915 & Reliable \\
\hline
\end{tabular}

Table 2

One-Sample Kolmogorov-Smirnov Test

\begin{tabular}{|c|c|c|c|c|c|c|}
\hline & & $\begin{array}{c}\text { Org. } \\
\text { Culture }\end{array}$ & $\begin{array}{c}\text { Environ- } \\
\text { ment }\end{array}$ & $\begin{array}{c}\text { Persona- } \\
\text { lity }\end{array}$ & $\begin{array}{l}\text { Motiva- } \\
\text { tion }\end{array}$ & $\begin{array}{c}\text { Job } \\
\text { Perfor- } \\
\text { mance }\end{array}$ \\
\hline$n$ & & 310 & 310 & 310 & 310 & 310 \\
\hline Normal & Mean & 95.16 & 94.98 & 93.30 & 95.18 & 102.45 \\
\hline Parameters ${ }^{\mathrm{a}, \mathrm{b}}$ & Std. Deviation & 9.176 & 7.084 & 9.903 & 9.453 & 7.674 \\
\hline Most Extreme & Absolute & .183 & .171 & .171 & .179 & .099 \\
\hline \multirow[t]{2}{*}{ Differences } & Positive & .183 & .171 & .171 & .179 & .099 \\
\hline & Negative & -.127 & -.130 & -.109 & -.130 & -.070 \\
\hline \multicolumn{2}{|c|}{ Test Statistic } & .183 & .171 & .171 & .179 & .099 \\
\hline \multicolumn{2}{|c|}{ Asymp. Sig.(2-tailed) } & $.000^{\mathrm{c}}$ & $.000^{\mathrm{c}}$ & $.000^{\mathrm{c}}$ & $.000^{\mathrm{c}}$ & $.000^{\mathrm{c}}$ \\
\hline
\end{tabular}

Table 3

Summary Results Calculation of Homogeneity Test

\begin{tabular}{lrrrrc}
\hline Variable & $\begin{array}{r}\text { Levene } \\
\text { Statistic }\end{array}$ & $\mathrm{df}_{1}$ & $\mathrm{df}_{2}$ & Sig. & Result \\
\hline$X_{4}$ by $X_{1}$ & 1.209 & 20 & 277 & .246 & Homogeneity \\
$X_{5}$ by $X_{1}$ & 1.315 & 20 & 278 & .449 & Homogeneity \\
$X_{4}$ by $X_{2}$ & 1.122 & 15 & 291 & .336 & Homogeneity \\
$X_{5}$ by $X_{2}$ & .797 & 15 & 292 & .681 & Homogeneity \\
$X_{4}$ by $X_{3}$ & .966 & 28 & 279 & .518 & Homogeneity \\
$X_{5}$ by $X_{3}$ & 1.057 & 28 & 280 & .391 & Homogeneity \\
$X_{5}$ by $X_{4}$ & 1.369 & 29 & 276 & .104 & Homogeneity \\
\hline
\end{tabular}


Table 4

Summary of Linearity Test and Significance Test Results

\begin{tabular}{cccccc}
\hline Path & Sig. & $>.05$ & $\mathrm{~F}_{\text {count }}$ & $\mathrm{F}_{\text {table }}$ & Result \\
\hline$X_{4}$ by $X_{1}$ & .705 & Linear & .843. & 2.6341 & Significant \\
$X_{4}$ by $X_{2}$ & .971 & Linear & .439 & 2.6341 & Significant \\
$X_{4}$ by $X_{3}$ & .560 & Linear & .937 & 2.6341 & Significant \\
$X_{5}$ by $X_{1}$ & .555 & Linear & .944 & 2.6341 & Significant \\
$X_{5}$ by $X_{2}$ & .889 & Linear & .592 & 2.6341 & Significant \\
$X_{5}$ by $X_{3}$ & .216 & Linear & 1.215 & 2.6341 & Significant \\
$X_{5}$ by $X_{4}$ & .724 & Linear & 0.883 & 3.8718 & Significant \\
\hline
\end{tabular}

\section{Test Data Homogenization}

A homogenization test is performed to determine that the sample data is derived from a population that has a variant or a diversity that is homogeneous or uniform. Test the statistics conducted to know the data homogeneity with Levene Statistics. All the data of the study come from a population that has a homogeneous variant because of sig. >.05. As seen in Table 3 .

The significance test and linearity of the simple linear regression model following the inter-variable relationship model formulated in the research model, that must be Sig. $>.05$ and also $F$-count $<F$-table, then it can be said that the relationship between organizational culture and motivation is linear, the relationship between environment and motivation is linear, the relationship between the personality and motivation is linear, the relationship between the organizational culture and job performance is linear, environment and job performance is linear. The relationship between personality and job performance is linear; the relationship between motivation and job performance is linear, as seen in Table 4.

\section{Hypothesis Testing Requirements}

Determination of the correlation coefficient between variables in structural models in Table 5 the entire correlation coefficient interrelated variables is positively marked, besides, the whole value of the correlation coefficient is significant because $r$-count $>.05$, this indicates that there is a positive correlation between variables. Based on the result of a path coefficient of counting is used to test the proposed hypothesis and measure the impact of both direct and indirect exogenous variables against endogenous variables in structural models. Withdrawal of the hypothesis conclusion is done through the calculation of the statistical value of each path coefficient, provided if $t_{\text {count }}>t_{\text {table }}$ The path coefficient is significant and vice versa if $t_{\text {count }}<t_{\text {table }}$ then path coefficient is not significant. Based on the calculation of SPSS 24, the correlation coefficient and path analysis are acceptable because of sig. $<.05$ as seen in Table 5.

\section{Hypothesis Proof}

$H_{1}$ : Organizational culture has a significant direct influence on motivation. Calculation results obtained that the path coefficient $X_{1}$ by $X_{4}\left(p_{41}\right)$ gets .142 with $t_{\text {count }}=2.672$. At $\alpha=.05$ retrieved $t_{\text {table }}=1.968$, because the value $t_{\text {count }}(2.672)>t_{\text {table }}(1.968)$. Then the path coefficient is very significant. It is proof that there is a significant direct influence on organizational culture to motivation $\left(X_{4}\right)$.

$\mathrm{H}_{2}$ : Environment has a significant direct influence on motivation. Calculation results obtained that the path coefficient $X_{2}$ by $X_{4}\left(p_{42}\right)$ gets .291 with $t_{\text {count }}=$ 5.370. At $\alpha=.05$ retrieved $t_{\text {table }}=1.968$. Because the value $t_{\text {count }}(5.370)>t_{\text {table }}(1.968)$, then the path coefficient is very significant. It is proof that there is a significant direct influence environment $\left(X_{I}\right)$ on motivation $\left(X_{4}\right)$.

$\mathrm{H}_{3}$ : Personality has a significant direct influence on motivation. Calculation results obtained that the line coefficient $X_{3}$ by $X_{4}\left(p_{43}\right)$ gets .150 with $t_{\text {count }}=$ 2.785. At $\alpha=.05$ gets $t_{\text {table }}=1.968$ because the value $t_{\text {count }}(2.785)>t_{\text {table }}(1.968)$, then the path coefficient is very significant. It is proof that there is a significant direct influence on organizational culture on trust $\left(X_{4}\right)$.

$\mathrm{H}_{4}$ : Organizational culture has a significant direct influence on job performance. Calculation results obtained that the line coefficient $X_{5}$ by $X_{1}\left(p_{51}\right)$ gets .260 with $t_{\text {count }}=4.984$. At $\alpha=.05$ retrieved $t_{\text {table }}=$ 1.968 , because the value $t_{\text {count }}(4.984)>t_{\text {table }}$ (1.968), Then the path coefficient is very significant. It is proof that there is a significant direct influence environment on motivation $\left(X_{4}\right)$.

$H_{5}$ : Environment has a significant direct influence on job performance. Calculation results obtained that the line coefficient $X_{2}$ by $X_{5}\left(p_{52}\right)$ gets .227 with $t_{\text {count }}$ $=4.279$. At $\alpha=.05$ retrieved $t_{\text {table }}=1.968$, because the value $t_{\text {count }}(4.279)>t_{\text {table }}(1.968)$. Then the path coefficient is very significant. Thus it is proof that there is a significant direct influence on organizational culture on job performance $\left(X_{5}\right)$.

$H_{6}$ : Personality has a significant direct influence on job performance. Calculation results obtained that the line coefficient $X_{2}$ by $X_{5}\left(p_{52}\right)$ gets .170 with $t_{\text {count }}=$ 3.2373. At $\alpha=.05$ retrieved $t_{\text {table }}=1.968$, because the value $t_{\text {count }}(3.237)>t_{\text {table }}(1.968)$, then the path 
Table 5

Findings of Research Hypotheses

\begin{tabular}{|c|c|c|c|c|c|}
\hline Hypotheses & $\begin{array}{l}\text { Correlation } \\
\text { Coefficient }\end{array}$ & $\begin{array}{c}\text { Path } \\
\text { Coefficient }\end{array}$ & $t_{\text {count }}$ & Sig. $<.05$ & Result \\
\hline $\begin{array}{l}\text { 1. Organizational culture has a significant } \\
\text { direct influence on motivation }\end{array}$ & $r_{14}=.165$ & $p_{41}=.142$ & 2.672 & .000 & Accepted \\
\hline $\begin{array}{l}\text { 2. The work environment has a } \\
\text { significant direct influence on } \\
\text { motivation }\end{array}$ & $r_{24}=.063$ & $p_{42}=.291$ & 5.370 & .000 & Accepted \\
\hline $\begin{array}{l}\text { 3. Personality as a significant direct } \\
\text { influence on the motivation }\end{array}$ & $r_{34}=.225$ & $p_{43}=.150$ & 2.785 & .000 & Accepted \\
\hline $\begin{array}{l}\text { 4. Organizational culture has a significant } \\
\text { direct influence on job performance }\end{array}$ & $r_{15}=.073$ & $p_{51}=.260$ & 4.984 & .001 & Accepted \\
\hline $\begin{array}{l}\text { 5. The work environment has a } \\
\text { significant direct influence on job } \\
\text { performance }\end{array}$ & $r_{25}=.095$ & $p_{52}=.227$ & 4.279 & .027 & Accepted \\
\hline $\begin{array}{l}\text { 6. Personality has a significant direct } \\
\text { influence on job performance }\end{array}$ & $r_{35}=.185$ & $p_{53}=.170$ & 3.237 & .000 & Accepted \\
\hline $\begin{array}{l}\text { 7. Motivation has a significant direct } \\
\text { influence on job performance }\end{array}$ & $r_{45}=.121$ & $p_{54}=.361$ & 2.998 & .002 & Accepted \\
\hline
\end{tabular}

coefficient is very significant. It is proof that there is a significant direct influence environment on job performance $\left(X_{5}\right)$.

$H_{7}$ : Motivation has a significant direct influence on job performance. Calculation results obtained that the line coefficient $X_{4}$ by $X_{5}\left(p_{54}\right)$ gets .169 with $t_{\text {count }}=$ 2.998. At $\alpha=.05$ retrieved $t_{\text {table }}=1.968$, because the value $t_{\text {count }}(2.998)>t_{\text {table }}(1.968)$, then the path coefficient is very significant. It is proof that there is a significant direct influence environment on job performance $\left(X_{5}\right)$.

$H_{8}$ : Organizational culture has significant indirect influence through motivation on the job performance. The next step is to determine the indirect influence of organizational culture through motivation on job performance, by doing the following calculations as follows:

$p_{541}=p_{41} \times p_{54}=.142 \times .361=.05415$

$s_{41}=.055$ (std. error) and $s_{54}=.055, S m=$ Std.

Error merge

$$
\begin{aligned}
& S m=\sqrt{\frac{(n 41-1) S 41^{2}+(n 54-1) S 54^{2}}{(n 41+n 54-2)}} \\
& S m=\sqrt{\frac{309(.055)^{2}+309(.055)^{2}}{618}} \\
& S m=\sqrt{\frac{.934725+.934725}{618}}=\sqrt{\frac{1.86945}{618}}=.055 \\
& t_{\text {count }}=\frac{p_{541}}{s m}=\frac{.05415}{.055}=.9845
\end{aligned}
$$

For $\alpha=.05$, and $d f=n-k-1=305$. On the test two parties obtained the value $t_{\text {table }}=1.967$. Because the value $t_{\text {count }}<t_{\text {table }}(.9845<1.967)$. Then it can be concluded that there is not a significant indirect influence of organization culture through motivation on job performance.

$H_{9}$ : Work environment has a significant indirect influence through motivation on the job performance. To determine the indirect influence of organizational culture through motivation on job performance job performance, by doing the following calculations as follows:

$$
\begin{aligned}
& p_{542}=p_{42} \times p_{54}=.291 \times .361=.1051 \\
& S_{42}=.061 \text { (std. error) and } s_{54}=.055 \\
& S m=\sqrt{\frac{(n 42-1) S 42^{2}+(n 54-1) S 54^{2}}{(n 42+n 54-2)}} \\
& S m=\sqrt{\frac{309(.061)^{2}+309(.055)^{2}}{618}} \\
& S m=\sqrt{\frac{1.149789+.934725}{618}}=\sqrt{\frac{2.084514}{618}}=.0581 \\
& t_{\text {count }}=\frac{p_{542}}{s m}=\frac{.1051}{.0581}=1.809
\end{aligned}
$$

For $\alpha=.05$, and $d f=n-k-1=305$. On the test two parties obtained the value $t_{\text {table }}=1.967$. Because the value $t_{\text {count }}<t_{\text {table }}(1.809<1,967)$. Then it can be concluded that there is not a significant indirect influence of environment through motivation on job performance.

$H_{10}$ : Personality has significant indirect influence through motivation on the performance. To determine the indirect influence of organizational culture through motivation on job performance job performance, by doing the following calculations as follows: 


$$
\begin{aligned}
& p_{543}=p_{43} \times p_{54}=.150 \times .361=.05415 \\
& S_{43}=.051 \text { (std. error) and } s_{54}=.055 \\
& S m=\sqrt{\frac{(n 43-1) S 43^{2}+(n 54-1) S 54^{2}}{(n 43+n 54-2)}} \\
& S m=\sqrt{\frac{309(.051)^{2}+309(.055)^{2}}{618}} \\
& S m=\sqrt{\frac{.803709+.934725}{618}}=\sqrt{\frac{1.738434}{618}}=.0530 \\
& t_{\text {count }}=\frac{p_{543}}{s m}=\frac{.05415}{.0530}=1.022
\end{aligned}
$$

For $\alpha=.05$, and $d f=n-k-1=305$. On the test, two parties obtained the value $t_{\text {table }}=1.967$. Because the value $\mathrm{t}_{\text {count }}<t_{\text {table }}(1.022<1,967)$. Then, it can be concluded that there is not a significant indirect influence of personality through motivation on job performance. Final structural model of influence variable exogenous on variable endogenous as seen Figure 2.

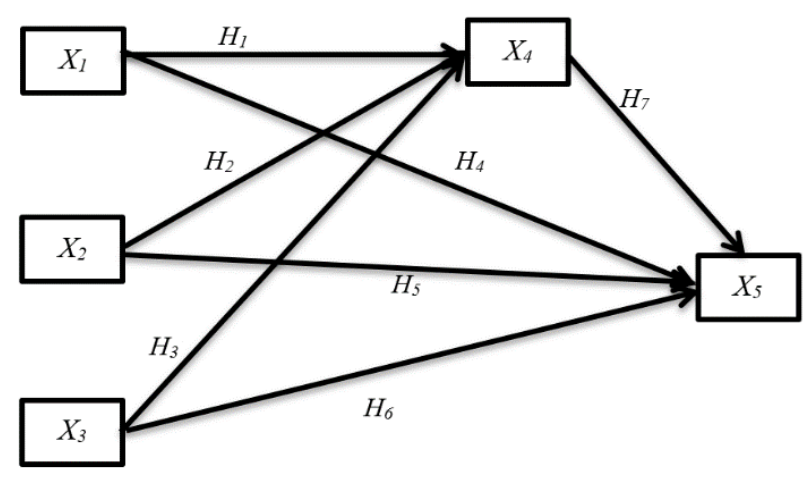

Figure 2. The last model structural

Based on the result of counting and testing of the path coefficient in Figure 2 can be interpreted, from a proven hypothesis that the research findings indicate the tendency variable of organizational culture, environment, personality have directly affect on motivation, then organizational culture, environment, personality, and motivation have directly influenced on job performance, and also personality has a significant indirect influence through motivation on the job performance of the stats school principal in Jakarta.

The first result of the study, organizational culture has a significant direct influence on motivation. The results of the study have been found by some researchers before that organizational culture is motivating (Copuš, Šajgalíková, \& Wojčák, 2019). Differences in the levels of motivation associated with different types of organizational culture (Janićijević et al., 2018). There's a positive impact of organizational culture on employee motivation (Weerasinghe, 2017).
The second result of the study that the environment has a significant direct influence on motivation. The results of the study have been found by some researchers before that the work environment affects the improving work motivation of the lecturers (Narasuci,Margono, \& Noermijati, 2018). The work environment is a force that encourages the spirit that is both inside and outside of itself as a reward or punishment (Prakoso, 2014). The physical work environment and non-physical work environment affect the motivation of employee work (Ingsiyah, Haribowo, \& Nurkhayati, 2019). Work environment that is safe, comfortable and conducive will increase a person's enthusiasm and enthusiasm so that the work that becomes his job can be resolved properly and on time as expected (Narasuci et al., 2018).

The third result of the study that personality has a significant direct influence on motivation. The results of the study have been found by some researchers before that the findings section has elaborated on the effect that personality has on the motivation of workers (Nuckcheddy, 2018). Which of the big five personality traits to expectancy motivation, neuroticism and conscientiousness were again the strongest correlates of expectancy motivation (Judge \& Ilies, 2002). Several personality dimensions, extraversion, agreeableness, conscientiousness, and intellect all have significant predictors in a positive direction to motivation (LjubinGolub, Petričević, \& Rovan, 2019).

The fourth result of the study that the organizational culture has a significant direct influence on job performance. The results of the study have been found by some researchers before that organizational culture significantly gives positive rise to the job performance of the individuals if the organization makes effort to enhance cultural orientation (Saad \& Abbas, 2018). the organizational culture has a great impact on employee's performance (Paschal \& Nizam, 2016). The study found that bureaucratic culture and innovative culture has a positive influence on the dependent variable (employee performance) (Nwakoby et al., 2019). That organizational culture has a significant positive impact on the performance of employee's jobs at selected software houses in Pakistan (Latif, Mushtaq, Muhammad, Ferdoos, \& Hummayoun, 2013). Organizational culture is still a significant predictor' of employee' performance (Maamari \& Saheb, 2018). organizational culture contributes positively to the prediction of employee's performance (Isa, Ugheoke, \& Noor, 2016; Mohammad, 2017; Indrasari, 2017).

The fifth result of the study that the environment has a significant direct influence on job performance. 
The results of the study have been found by some researchers before that the was an effect on the major physical conditions on job performance (Al-Omari \& Okasheh, 2017; Lankeshwara, 2016; Samson, Waiganjo, \& Koima, 2015). There were influences working environment components (i.e. top management, esteem needs and work hours, and job security, safety, and workplace relationships) on job satisfaction (Raziq \& Maulabakhsh, 2015).

The sixth result of the study that personality has a significant direct influence on job performance. The results of the study have been found by some researchers before the conclusion to be inferred is that job complexity is a strong moderator of the validity of personality measures (Salgado, 2017). Human personality traits are highly related to job performance (Dhani, 2017; Ahmad, Razzaq, \& Hussain, 2014; Abdullah, Omar, \& Rashid, 2013). All factors have a significant relationship with employee productivity except. Extraversion, Agreeableness, and Consciousness has a positive relationship with employee productivity (Najam-us-Sahar, 2016).

The seventh result of the study that motivation has significant direct influence on job performance. The results of the study have been found by some researchers before that intrinsic motivation has a significant positive relationship on job satisfaction (Arasl, Daşkın, \& Saydam, 2014). We can conclude that intrinsic and extrinsic motivation is useful for predicting job satisfaction (Ogunnaike, Akinbola, \& Ojo, 2014; Hayati \& Caniago, 2012). Ability and motivation have partially a significant positive direct effect on employee job satisfaction at the Directorate General of State Treasury (DJPBN) of Southeast Sulawesi Province (Jasiyah, Ramli, \& Sinring, 2018).

The results of this research are organizational culture, work environment, and personality directly effects on the motivation of work and also on job performance. It is following the real conditions of the school principals in Jakarta ranging from middle school and high school, that organizational culture, has given to the principal how to work properly accordance with applicable habits and regulations. With organizational culture this is the school head motivated to work. It is therefore important to be held meeting school headmaster scheduled by the education office to improve the culture of work in the Organization, so that would be an improvement in motivation. Besides, with the understanding of organizational culture by the principal will affect the improvement of job performance in each school.

Generally, schools in Jakarta have adequate equipment for work, because the education office always complements the needs of the school through the proposal from the principal, as well as the work atmosphere in the office is quite conducive to the mutual Appreciate among your colleagues. Such conditions of work environment like that in addition to creating work motivation for the principal to work better will also affect the job performance of the principal. Therefore, with the maintenance of both facilities and infrastructure and the construction of the work atmosphere will improve Job performance.

Generally speaking, principal schools in Jakarta have been in a selection that has personalities that can work as principals, through general knowledge, Psycho Test, interviews, and assessment by friends and employers. So this personality has inherent in the school principal, with the personality of the school principal must have a high motivation because they will motivate the teacher to work properly, also should motivate the students to learn well. Thereby through personality and motivation work will affect job performance. Therefore, to overview the job performance of the headmaster should be increased through his expertise and motivation, but in this study motivation as variable intervening did not work properly on influencing of job performance of the principal.

\section{Conclusions and Implications}

Based on the results of research on 310 principals of junior high schools, senior high schools, vocational high schools in Jakarta by using path analysis, it can be concluded that the school principal motivation directly influenced by variations organizational culture, work environment, and personality. Likewise, that job performance is directly influenced by variations in organizational culture, work environment, personality, and motivation. But there were not an indirect influence organizational culture, work environment, personality through motivation on job performance, In this case variable intervening (work motivation) is not effective in contributing influence on job performance.

Based on the results of the study have several implications for Education Office, And Special Regional Government of Jakarta. In connection with the findings of this research, the Provincial Education Office of Jakarta and the Special Regional Government of Jakarta have to pay more attention to the significant role of organizational culture, work environment, and personality, while the work motivation itself has the biggest influence on job performance when compared with three other variables. This can happen as such because the 
Local Government of Jakarta has given significant remuneration to its employees. Recruitment planning of prospective headmaster in the future through a personality test that includes a big five personality test. As for the current school principal to be given the construction on a periodic basis, for example through an outbound program to improve the character building, with the program to improve organizational culture, work environment, and personality.

\section{Research Limitations and Guidance for Future Research}

In every study, there are several limitations, as well as in this study. For that further research is required. First, the number of samples of this research was only 310 principals of elementary schools, junior high school, the senior high school in the country. Researchers realized that the sample has not represented the entire school principal in Indonesia. Second, the scope of research is limited to four variables as independent variables and one dependent variable e.g. organizational culture, work environment, personality, motivation, and job performance. Guidance for future research we recommend other researchers in the field of management and human resources, for further research to examine direct and indirect influences by using other variables independent of variable job performance and using larger samples in the wider area of coverage.

\section{References}

Abdullah, I., Omar, R., \& Rashid, Y. (2013). Effect of personality on organizational commitment and employees' performance: Empirical evidence from banking sector of Pakistan. World Applied Sciences Journal, 27(1), 140-147. https://doi.org/10.5829/ idosi.wasj.2013.27.01.1685

Ahmad, J., Razzaq, M., \& Hussain, M. (2014). Impact of big five personality traits on job performance (Organizational commitment as a mediator). Management, Knowledge and Learning International Conference 2014, 1, 571-577.

Al-Omari, K., \& Okasheh, H. (2017). The influence of work environment on job performance: A case study of engineering company in Jordan. International Journal of Applied Engineering Research, 12(24), 15544-15550.

Araslı, H., Daşkın, M., \& Saydam, S. (2014). Polychronicity and intrinsic motivation as dispositional determinants on hotel frontline employees' job satisfaction: Do control variables make a difference? Procedia - Social and Behavioral Sciences, 109, 1395-1405. https://doi.org/10.1016/j.sbspro. 2013.12.643.

Berková, K., \& Krejčová, K. (2016). Effect of teachers' abilities on students' motivation with varying levels of intellectual abilities in the economics. ERIES Journal, 9(3), 1712-1713. https://doi.org/ 10.7160/eriesj.2016.090304.Introduction

Borys, D. (2014). Organisational culture: Determining knowledge-sharing attitudes. In M. Handzic (Ed.), Socio-Technical Knowledge Management: Studies and Initiatives. Hershey. PA: IGI Global. https://doi.org/10.4018/978 1599045498. ch017

Cacioppo, J. T., \& Petty, R. E. (1982). The Need for cognition. Journal of Personality and Social Psychology, 42(1), 116-131. https://doi.org/10.1080/ 13183222.2018.1418978

Chapman, B. P., Roberts, B., \& Duberstein, P. (2011). Personality and longevity: Knowns, unknowns, and implications for public health and personalized medicine. Journal of Aging Research, 2011. https://doi.org/10.4061/2011/759170

Colquitt, J. A., LePine, J. A., \& Wesson, M. J. (2019). Organizational behavior: Improving performance and commitment in the workplace. $6^{\text {th }}$ Edition. New York, NY: McGraw-Hill.

Copuš, L., Šajgalíková, H., \& Wojčák, E. (2019). Organizational culture and its motivational potential in manufacturing industry: subculture perspective. Procedia Manufacturing, 32, 360-367. https://doi. org/10.1016/j.promfg.2 019.02.226

Dhani, P. (2017). Personality and job performance. Kaav International Journal of Economic, 4 (2), 177-183. https://doi.org/10.1207/s15327 043hup1102\&3_1

Eide, A. E., Saether, E. A., \& Aspelund, A. (2020). An investigation of leaders' motivation, intellectual leadership, and sustainability strategy in relation to Norwegian manufacturers' performance. Journal of Cleaner Production, 254, 1-12. https://doi.org/ 10.1016/j.jclepro.2 020.120053

Eliyana, A., Ma'arif, S., \& Muzakki. (2019). Job satisfaction and organizational commitment effect in the transformational leadership towards employee performance. European Research on Management and Business Economics, 25(3), 144-150. https://doi. org/10.1016/j.iedeen.2019.05.001

Fandiño, F. G. E., Muñoz, L. D., \& Velandia, A. J. S. (2019). Motivation and e-learning English as a foreign language: A qualitative study. Heliyon, 5(9), 1-7. https://doi.org/10.1016/j.heliyon.2019. e02394 
Farhan, B. Y. (2018). Application of path-goal leadership theory and learning theory in a learning organization. Journal of Applied Business Research, 34(1), 13-22. https://doi.org/10.19 030/jabr. v34i1.10088

Farooqui, M. S., \& Nagendra, A. (2014). The impact of person organization fit on job satisfaction and performance of the employees. Procedia Economics and Finance, 11(14), 122-129. https://doi. org/10.1016/s2212-5671(14)0 0182-8

Fayol, H., \& Storrs, C. (1954). General and industrial mangaement Retrieved from https://ia80 1600.us. archive.org/4/items/in.ernet.dli.2015.13518/2015. 13518.General-And-Industrial-Management.pdf

Gagné, M., \& Deci, E. L. (2005). Self-determination theory and work motivation. Journal of Organizational Behavior, 26(4), 331-362. https://doi.org/ 10.1002/job.322

Ghani, N. M. A., Yunus, N. S. N. M., \& Bahry, N. S. (2016). Leader's personality traits and employees job performance in public sector, Putrajaya. Procedia Economics and Finance, 37 (16), 46-51. https://doi.org/10.1016/s2212-56 71(16)30091-0

Gibson, J. L., Ivancevich, J. M., Donnelly Jr., J. H., \& Konopaske, R. (2012). Organization: Behavior structure processes. New York: NY: McGrawHill.

Hanaysha, J. (2016). Testing the effects of employee engagement, work environment, and organizational learning on organizational commitment. Procedia - Social and Behavioral Sciences, 229, 289 297. https://doi.org/10.1 016/j.sbspro.2016.07.139

Hayati, K., \& Caniago, I. (2012). Islamic work ethic: The role of intrinsic motivation, job satisfaction, organizational commitment and job performance. Procedia - Social and Behavioral Sciences, 65, 272-277. https://doi.org/10.1016/j.sbspro.2012.11. 122

Hober, B., Schaarschmidt, M., \& von Korflesch, H. (2019). Internal idea contests: Work environment perceptions and the moderating role of power distance. Journal of Innovation and Knowledge, 30(2019), 1-10. https://doi.org/ 10.1016/j.jik.2019. 11.003

Indrasari, M. (2017). The effect of organizational culture, environmental work, leadership style on the job satisfaction and its impact on the performance. Sinergi, 7, 58-73.

Ingsiyah, H., Haribowo, P., \& Nurkhayati, I. (2019). Effect of working environment on employee motivation at PT. Pupuk Sriwidjaja Palembang, Pusri Central Java regional marketing. Admisi Dan Bisnis, 20(1), 83.
Isa, M. F. M., Ugheoke, S. O., \& Noor, W. S. W. M. (2016). The influence of organizational culture on employees' performance: Evidence from Oman. Journal of Entrepreneurship and Business, 4(2), 112. https://doi.org/10.17687/jeb.0402.01

Ismail, A., Anuar, A., \& Abdullah, A. A. (2016). Reward management on motivation to perform job. Jurnal Manajemen dan Kewirausahaan. 18(2), 83-90. https://doi.org/10.9744/ jmk.18.2.83-90

Jain, R., \& Kaur, S. (2014). Impact of work environment on job. International Journal of Scientific and Research Publucation, 4(1), 1-8.

Janićijević, N., Nikčević, G., \& Vasić, V. (2018). The influence of organizational culture on job satisfaction. Economic Annals, 63(219), 83-114. https://doi.org/10.2298/EKA1819083J

Jasiyah, R., Ramli, H. M., Sinring, H. B., \& Sukmawati, S. (2018). The effect of ability and motivation on job satisfaction and employee performance. Archives of Business Research, 6(12), 12-23. https://doi.org/10.14738/abr.61 2.5644

Judge, T. A., \& Ilies, R. (2002). Relationship of personality to performance motivation: A metaanalytic review. Journal of Applied Psychology, 87(4), 797-807. https://doi.org/10.1037 /00219010.87.4.797

Langton, N., Robbins, S. P., \& Judge, T. A. (2016). Organizational behaviour: Concepts, controversies, applications. Seventh Canadian Edition. Toronto, Canada: Perason.

Lankeshwara, P. (2016). A study on the impact of workplace environment on employee's performance: With reference to the Brandix intimate apparel Awissawella. International Journal of Multidisciplinary Studies, 3(1), 47-57. https://doi.org/10. 4038/ijms.v3i1.82

Latif, M. S., Mushtaq, A., Muhammad, Q., Ferdoos, A., \& Hummayoun, N. (2013). Impact of employee's job satisfaction on organizational performance. European Journal of Business and Management, 5(5), 166-171.

Ljubin-Golub, T., Petričević, E., \& Rovan, D. (2019). The role of personality in motivational regulation and academic procrastination. Educational Psychology, 39(4), 550-568. https:// doi.org/10.1080/ 01443410.2018 .1537479

Maamari, B. E., \& Saheb, A. (2018). How organizational culture and leadership style affect employees' performance of genders. International Journal of Organizational Analysis, 26 (4), 630651. https://doi.org/10.1108/IJOA-0 4-2017-1151 
Mextaria, Y., Sukmawati, A., \& Hubeis, A. V. S. (2019). The evaluation of lecturer's performance and sekolah tinggi perikanan's performance through intellectual capital. Jurnal Manajemen, 23(1), 19. https://doi.org/10.24912/j m.v23i1.442

Mohammad, Z. (2017). The effect of organizational culture and working environment on employee performance: Study on the example of printing company. RJOAS, 12, 81-85.

Nai, H., \& Wiwik, W. (2018). The implementation of duties and functions of state high school principals. Jurnal Akuntabilitas Manajemen Pendidikan, 6(2), 183-192.

Najam-us-Sahar, J. (2016). Impact of personality type on job productivity. Journal of Hotel \& Business Management, 5(1), 1-9. https://doi. org/10.4172/ 2169-0286.1000119

Nam, Y., \& Kim, H. (2016). A study on the effect of industry organizational culture on job attitude of organizational employees - Comparison between the semiconductor and the automobile industries. Procedia Computer Science, 91, 581-590. https://doi.org/10.1016/j.p rocs.2016.07.149

Narasuci, W., Margono, S., \& Noermijati, N. (2018). Effect of work environment on lecturer performance mediated by work motivation and job satisfaction. Jurnal Aplikasi Manajemen, 16(4), 645-653. https://doi.org/10.2177 6/ub.jam.2018. 016.04.11

Nuckcheddy, A. (2018). The effect of personality on motivation and organisational behaviour. Psychology and Behavioral Science International Journal, 9(2). https://doi.org/10.19080/pbsij.2018.09.555760

Nwakoby, N. P., Okoye, J. F., \& Anugwu, C. C. (2019). Effect of organizational culture on employee performance in selected deposit money banks in Enugu State. Journal of Economics and Business, 2(4), 1213-1225. https://doi.org/10.31014/aior. 1992.02.04.162

Ogunnaike, O. O., Akinbola, O. A., \& Ojo, O. A. (2014). Effect of motivation on job satisfaction of selected sales representatives. Journal of Educational and Social Research, 4(1), 197-203. https://doi.org/ 10.5901/jesr.2014.v4n1p197

Paschal, A. O., \& Nizam, D. I. (2016). Effects of organisational culture on employees performance. International Journal of Accounting and Business Management, 4(1), 19-26. https://d oi.org/10.24924/ ijabm/2016.04/v4.iss1/19.26

Permendikbud Nomor 6. Tugas dan fungsi kepala sekolah. Pub. L. No. 6 Tahun 2018, 15 (2018).
Prakoso, R. (2014). Environmental impact of work motivation and employee performance PT. AXA Financial Indonesia Cabang Malang. Jurnal Administrasi Bisnis S1 Universitas Brawijaya, 14(2), 110.

Raziq, A., \& Maulabakhsh, R. (2015). Impact of working environment on job satisfaction. Procedia Economics and Finance, 23, 717-725. https://doi. org/10.1016/s22125671(15)00524-9

Riduwan, R. (2011). Path analysis (Analisis jalur). Bandung: Alfabeta.

Saad, G. B., \& Abbas, M. (2018). The impact of organizational culture on job performance: A study of Saudi Arabian public sector work culture. Problems and Perspectives in Management, 16(3), 207-218. https://doi.org/10.21 511/ppm.16(3).2018. 17.

Safaria, T., Tentama, F., \& Hadi, S. (2016). Cyberbully, cybervictim, and personality profile among Indonesian junior high school students. The Turkish Online Journal of Educational Technology, 15(3), 40-48.

Salgado, J. F. (2017). Moderator effects of job complexity on the validity of forced-choice personality inventories for predicting job performance. Revista de Psicologia Del Trabajo y de Las Organizaciones, 33(3), 229-238. https://doi.org/10.1016/ j.rpto.2017.07.001

Samson, G. N., Waiganjo, M., \& Koima, J. (2015). Effect of Workplace Environment on the Performance of Commercial Banks Employees in Nakuru Town. International Journal of Managerial Studies and Research (IJMSR), 3 (12), 76-89.

Singh, K. (2016). Influence of internal service quality on job performance: A case study of royal police department. Procedia - Social and Behavioral Sciences, 224, 28-34. https://doi.org/10.1016/ j.sbspro.2016.05.396

Sutanto, E. M., Scheller-Sampson, J., \& Mulyono, F. (2018). Organizational justice work environment and motivation. International Journal of Business and Society, 19(2), 313-322.

Teo, S. T. T., Bentley, T., \& Nguyen, D. (2019). Psychosocial work environment, work engagement, and employee commitment: A moderated, mediation model. International Journal of Hospitality Management, (in press). https://doi.org/10.1016/ j.ijhm.2019.102415

Thiruvarasi, M., \& Kamaraj, M. (2017). Influence of big five personality on organizasional commitment, emitional intelligence and job satisfaction. Asia Pacific Journal of Research in Business Management, 8(6), 37-51. 
Virgana, V. (2018). The increasing performance of school principal through remuneration, personality, and job satisfaction. International Journal of Human Capital Management, 2(2), 45 -59.

Weerasinghe, G. (2017). Organization culture impacts on employee motivation: A case study on an apparel company in Sri Lanka. International Journal of Multidisciplinary Research and Development, 4(4), 59-62.
Zhu, Y. A. N., \& Leung, F. K. S. (2011). Motivation and Achievement: Is there an East Asian. International Journal of Science and Mathematics Education, 9, 1189-1212. https://doi.org/ 10.1007/s10763-0109255-y.

Zlate, S., \& Cucui, G. (2015). Motivation and performance in higher education. Procedia - Social and Behavioral Sciences, 180,468-476. https://doi.org/ 10.1016/j.sbspro.2015.02.146. 
